\title{
SYMPOSIUM ON SOVEREIGNTY, CYBERSPACE, AND TALLINN MANUAL 2.0
}

\author{
IN DEFENSE OF SOVEREIGNTY, IN THE WAKE OF TALLINN 2.0
}

Pbil Spector*

One of the gentle surprises of the release of the Tallinn 2.0 Manual is that it has prompted a rich debate over the nature of sovereignty in international law. In hindsight, this should not be too surprising. The modern, Westphalian project of international law is built in large measure around the state and its borders. The emergence of a technology that so readily defies those borders was bound to kick up some interpretive dust. And it appears to have done even more than that. Depending on your perspective, the Tallinn translation of international law to the cyber domain has either forced a reconsideration or surfaced a latent dispute over whether sovereignty is a binding rule of international law at all.

Others in this Symposium are writing about the implications of this debate for the present and the future of cyber operations, asking questions about the constraints sovereignty imposes on cyber activities by states, which approach to sovereignty is most compelling from a policy or operational perspective, and what all of this means when refracted through the lens of other interlocking doctrines of international law. ${ }^{1}$

I would like to use this space to look behind us instead, and to linger on foundational questions on which the Tallinn 2.0 Manual itself could only briefly touch: What is the doctrinal basis for the claim that sovereignty is a binding principle of international law in the first place? And why might one conclude that such a principle constrains state conduct below a use of force threshold?

A caveat: although I was a member of the Group of Governmental Experts for Tallinn 2.0, I am expressing here my own views, and not those of the Group or any of its members. Nothing herein is intended to speak to the content of the group's deliberations on sovereignty, or the rest of the cyber-international-law puzzle.

\section{An Accumulation of Doctrine}

No one denies that that there is a principle known as sovereignty in international law. But the critic will claim that it is only that - a background principle rather than a primary rule — and that it binds states only inasmuch as it informs other rules of international law, most prominently those prohibiting the threat or use of force or intervention in the internal affairs of other states. This argument tends to dwell on provisions such as Article 2(4) of the UN Charter, which references the "territorial integrity" of a state but provides only that "[a]ll members shall refrain in their international relations from the threat or use of force" against that integrity. ${ }^{2}$

* Member of the Tallinn 2.0 Group of Governmental Experts. He is a founding partner of the law firm of Messing \& Spector LLP and a Visiting Clinical Lecturer of Law at Yale Law School.

${ }^{1}$ Gary P. Corn \& Robert Taylor, Sovereignty in the Age of Cyber, 111 AJIL Unbound 207 (2017); Michael N. Schmitt \& Liis Vihul, Sovereignty in Cyberspace: Lex Lata Vel Non?, 111 AJIL Unbound 213 (2017); Ahmed Ghappour, Tallinn, Hacking, and Customary International Law, 111 AJIL UnBound 224 (2017).

2 UN Charter art. 2(4).

\footnotetext{
The American Society of International Law and Phil Spector (C) 2017. This is an Open Access article, distributed under the terms of the Creative Commons Attribution licence (http://creativecommons.org/licenses/by/4.0/), which permits unrestricted re-use, distribution, and reproduction in any medium, provided the original work is properly cited.
} 
But even the Charter also conspicuously describes the United Nations as premised on the "sovereign equality" of its Members. ${ }^{3}$ And elsewhere, international legal texts go quite a bit further. For example, the 1970 UN Declaration on Principles of International Law Concerning Friendly Relations and Co-operation Among States (which is understood to reflect customary international law) begins its enumeration with the "principle that States shall refrain in their international relations from the threat or use of force," and the "principle concerning the duty not to intervene in matters within the domestic jurisdiction of any State." But the Declaration then proceeds to address separately the "principle of sovereign equality" of states. The Declaration lists several of the "elements" of sovereign equality, including the ideas that "[e]ach State enjoys the rights inherent in full sovereignty" and "[t]he territorial integrity and political independence of the State are inviolable."4

The sovereignty of a state over its territory is woven into countless other international treaties as well. Both the 1944 Convention on International Civil Aviation (the Chicago Convention) and the 1970 International Law of the Sea Convention start with an articulation of the principle of the sovereignty of states over their airspace and the territorial seas, respectively. ${ }^{5}$ The Helsinki Accords require participating states to "respect each other's sovereign equality ... as well as all the rights inherent in and encompassed by its sovereignty," principles that it treats separately from the use of force or the principle of nonintervention. ${ }^{6}$ Numerous UN Security Council authorizations affirm the sovereignty and territorial integrity of states. ${ }^{7}$ The list goes on and on.

But even if some of this language — which by its nature is general and declaratory-were to leave doubt as to whether sovereignty represents its own binding norm apart from others such as the principle prohibiting the use of force, international tribunals over the years have been clear on the matter.

In 1927, the PCIJ in the Lotus case opined, "Now the first and foremost restriction imposed by international law upon a State is that - failing the existence of a permissive rule to the contrary-it may not exercise its power in any form in the territory of another State." ruled, "[t]erritorial sovereignty, as has already been said, involves the exclusive right to display the activities of a State."

Shortly after the entry into force of the UN Charter, the ICJ took up this thread in the Corfu Channel case, observing that "between independent States the respect for territorial sovereignty is an essential foundation for international relations." ${ }^{10}$ In his separate opinion in the case, Judge Alvarez elaborated, "[b]y sovereignty, we understand the whole body of rights and attributes which a State possesses in its territory, to the exclusion of all other States, and also in its relations with other States." 11 As recently as 2015, the ICJ held that Nicaragua had violated the "territorial sovereignty" of Costa Rica by conducting certain activities related to the dredging of a river on its territory, without reaching a conclusion on the separate claim that these activities had violated the UN Charter's prohibition on the use of force. ${ }^{12}$

\footnotetext{
${ }^{3}$ UN Charter arts. 2(1), 78.

${ }^{4}$ GA Res. 2625 (XXV) (Oct. 24, 1970).

${ }^{5}$ Convention on International Civil Aviation art. 1, Dec. 7, 1944, 15 UNTS 295; United Nations Convention on the Law of the Sea art. 2 (1), Dec. 10, 1982, 1833 UNTS 397.

${ }^{6}$ The Final Act of the Conference on Security and Cooperation in Europe, Aug. 1, 1975, 14 I.L.M. 1292.

7 See, e.g., SC Res. 1808 (Apr. 15, 2008) (Georgia); SC Res. 1244 (June 10, 1999) (Yugoslavia); SC Res. 1272 (Oct. 25, 1999) (Indonesia).

8 The S.S. Lotus (Fr. v. Turk.), 1927 P.C.I.J. (ser. A) No. 10 (Sept. 7) (emphasis added).

${ }^{9}$ Island of Palmas (Neth. v. U.S.), 2 R.I.A.A 829, 838 (Perm. Ct. Arb. 1928); Paul Guggenheim, Lehrbuch des VölKerrechts (1948) (Ger.).

${ }^{10}$ Corfu Channel (U.K. v. Alb.), Merits, 1949 ICJ Rep. 4, 35 (Apr. 9).

${ }^{11} \mathrm{Id}$. at 43 (individual opinion of Alvarez J.).

12 Certain Activities Carried Out by Nicaragua in the Border Area (Costa Rica v. Nicar.) and Construction of a Road in Costa Rica along the San Juan River (Costa Rica v. Nicaragua), para. 65-93, 96-97-229 (Dec. 16, 2015).
} 
Even the Nicaragua decision — often understood as a decision regarding the use of force and noninterventionin fact went further. After examining each of the use of force and nonintervention rules, the ICJ went on to identify a separate "duty of every State to respect the territorial sovereignty of others." ${ }^{13}$ The Court located this rule in Article 2(1) of the UN Charter, the Chicago Convention, and the Convention on the Law of the Sea. But it also explained that it "has no doubt that these prescriptions of treaty-law merely respond to firmly established and longstanding tenets of customary international law."14

In light of the above, it is unsurprising that leading international law scholars and texts have also long taken the view that there is a binding, primary rule of international law regarding territorial sovereignty. For example, Antonio Cassese describes how " $[\mathrm{t}]$ raditional international law was based on a set of rules protecting the sovereignty of States and establishing their formal equality in law." ${ }^{15} \mathrm{He}$ goes on to underscore that "[s]overeignty includes sweeping powers and rights," one of which he identifies as the "right that no other State intrude in the State's territory (the so-called jus excludendi alios, or the right to exclude others)." "He explains that "[s]tates have always vigorously protested and claimed compensation when foreign States have exercised on their territory public activities that had not been previously authorized." 17 And he then sketches examples stretching back to the early Twentieth Century. ${ }^{18}$ This entire discussion is separate from his treatment of use of force or nonintervention.

Oppenheim's International Law is replete with similar statements. Over the years, the treatise has emphasized that it "follows from the principle of territorial supremacy that States must not perform acts of sovereignty within the territory of other States,"19 recognized the "power of a state to exercise supreme authority over all persons and things within its territory, “ 20 and described how "the exercise of a state's sovereign authority" in the territory of another without its consent will constitute a "violation of [the state's] territorial authority." 21

The most telling example might be Louis Henkin. Henkin voiced frustration at the use of the principle of sovereignty in light of the ways in which it had been wielded by nations to try to resist the implications of international law or treaties. ${ }^{22} \mathrm{He}$ argued that it would be better to "decompose" sovereignty into the several "essential characteristics" of statehood today. ${ }^{23} \mathrm{He}$ explained that one of those characteristics is "territorial integrity and authority." Tracing the inviolability of territory to the time and "the law of princes," he elaborated:

In the modern inter-state system, too, the state has complete authority in its territory and over persons, activities and things within it (except as it consents to waive some of that authority). Other states may not occupy any of a state's territory, or penetrate it, or exercise authority within it, or interfere with or intervene in its governance, without consent. ${ }^{24}$

Thus, even Henkin recognized the presence of a rule protecting the territory of a state from incursion by another.

${ }^{13}$ Military and Paramilitary Activities in and against Nicaragua (Nicar. v. U.S.), Merits, 1986 ICJ Rep. 14, para. 213 (June 27 ).

${ }^{14}$ Id. at paras. $212-14$.

15 Antonio Cassese, International LaW 48 (2d ed. 2004).

${ }^{16} I d$. at 51.

${ }^{17} \underline{I d}$.

${ }^{18} \overline{I d}$.

19 Oppenheim's International Law 327-28 (H. Lauterpacht ed., 8th ed. 1955).

20 Oppenheim's International Law 432 (Robert Jennings \& Arthur Watts eds., 9th ed. 2008).

21 Id. at 385 .

22 Louis Henkin, International Law: Politics and Value 8-9 (1995).

${ }^{23}$ Id. at $10-11$.

${ }^{24} \mathrm{Id}$. at 12. 
Whether one chooses to call it sovereignty, or territorial sovereignty, or territorial integrity, or something else entirely, an overwhelming and unavoidable body of treaties, jurisprudence, and scholarly opinion stands for the proposition that there is a primary rule of international law that requires one state to refrain from taking a public act or exercising authority in the territory of another state, in the absence of consent or another provision of international law to the contrary.

\section{Below the Use of Force}

Those who dispute the existence of a sovereignty rule might nonetheless press on. They might argue that it was easy enough for these past opinions to indulge in sweeping language to describe international law in this area, because until recently, most of the ways in which a state might act inside the territory of another state were physical incursions that rose to the level of a threat or use of force, and so the cost of such an exaggerated treatment of the law was slight. Cyberspace, on the other hand, dramatically expands the tool box of ways in which one state may be able to act in another state below the threshold of the use of force. Now that cyber operations below the use of force are more commonplace, the argument might go, it is time to recognize these prior statements for what they always were-expressions of the actual rules against the use of force and nonintervention.

In truth, however, the international law of sovereignty has always covered a broad range of activities that do not rise to the use of force threshold. A few examples are illustrative.

First, even one state's nonmilitary overflights into another state's territory are understood to violate the sovereignty of that state. The Chicago Convention sets out sovereignty as the default rule for overflights, stating that "[t]he contracting States recognize that every State has complete and exclusive sovereignty over the airspace above its territory," and further that "[n]o state aircraft of a contracting State shall fly over the territory of another State or land thereon without authorization by special agreement or otherwise, and in accordance with the terms thereof." 25

The Nicaragua case affirmed that the "principle of respect for territorial sovereignty is also directly infringed by the unauthorized overflight of a State's territory by aircraft belonging to or under the control of the government of another State." 26 The Court in that case applied this principle to find that U.S. unarmed overflights of Nicaragua had violated the sovereignty of that country, without citing the prohibition on use of force or any other international law principles on that point. ${ }^{27}$

Second, the same is true of one state undertaking a law enforcement investigation in another state without the latter's consent. ${ }^{28}$ As one scholar explains it, "it is generally not necessary to define precisely what gives rise to the affront to sovereignty in this context, because two objectionable actions go hand in hand: the physical entry of a foreign state's officials and the subsequent search or seizure of person[s] or property." 29 This principle extends to an officer entering a neighboring state without consent merely to interrogate someone "with a view to gaining information" or to "pursue criminals" who fled over the border, even in hot pursuit. ${ }^{30}$

${ }^{25}$ Chicago Convention on International Civil Aviation arts. 1, 3(c), Dec. 7, 1944, 15 UNTS 295.

${ }^{26}$ Military and Paramilitary Activities in and against Nicaragua, supra note 13, at para. 251.

27 Id. at paras. $88,251$.

28 Restatement (Third) of the Foreign Relations Law of the United States sec. 432(2) (“A state’s law enforcement officers may exercise their functions in the territory of another state only with the consent of the other state.") [hereinafter RESTATEMENT (THIRD)].

${ }^{29}$ Patricia L. Bellia, Chasing Bits Across Borders, 2001 U. CHI. L.F. 35, 64.

301 OpPenheim's International LaW, supra note 19, at 387. 
Third, it is also a violation of the sovereignty of a foreign state "to exercise an act of administration or jurisdiction on foreign territory" without the consent of another state. ${ }^{31}$ Examples here might include sending customs officials or weapons inspectors or tax or judicial officers into another state without permission. ${ }^{32}$

Again, in each of these instances, the conduct in question is seen as a violation of sovereignty, not of the prohibition on the use of force or any other rule of international law. Neither is there any claim that the state whose sovereignty is violated would be entitled to respond with force to the violation of international law.

Of course, the fact that there is an international law rule protecting the sovereignty of a state-in cases that fall short of a use of force threshold and do not trigger a principle of nonintervention-is only the very start of the inquiry into the international law of cyber activities not the end. There remain questions about the nature and magnitude of actions that trigger a violation of sovereignty in the realm of cyberspace. The law in other areas involving intangible incursions, including transfrontier pollution ${ }^{33}$ and the broadcast and jamming of radio signals, ${ }^{34}$ may be instructive here.

There are thorny questions about how the sovereignty rule interacts with orbiting principles such as countermeasures, due diligence, and necessity. And it is even fair to ask whether our accumulated understanding of the international law of sovereignty ought to be reconsidered or refined in light of the unique circumstances and pressures of cyberspace.

Tallinn 2.0 sought to advance the conversation into these questions - and it did so quite cautiously at that, with all of the experts agreeing that at least some cyber operations that result in a loss of functionality in another state violate the sovereignty of that state, but reaching no consensus on other kinds of operations. This is a conversation the international law community is certain to continue in the years ahead. But in doing so, we will need to engage the international law of sovereignty as it actually exists—not simply cast it aside.

${ }^{31}$ Id. at 386; Restatement (Third), supra note 28, sec. 432, cmt. B, Reporters' Notes 1, 3.

32 Restatement (Third), supra note 28 , note 10.

33 See, e.g., Albrecht Randelzhofer, Transfrontier Pollution, in 4 Encyclopedia of Public International Law $913-15$ (2002) (discussing how a state's activities resulting in pollution that crosses the border into another state and causes appreciable damage to that state's environment implicates principles of territorial sovereignty and integrity).

34 See, e.g., 1 Oppenheim's International Law, supra note 19, at 529 (arguing that the "principle of exclusive sovereignty in the air space for the subjacent State ... enables that State to prohibit the disturbance of the air space over its territory by means of Herzian waves caused for the purpose of wireless communication and emanating from a foreign source"). 